\title{
The Relation Between Heavy Metals Distribution and Particle size Fractions in Some Egyptian Soils
}

\author{
Monier Morad Wahba* \\ Soils and Water Use Department, National Research Centre El-Tahrirstreet \\ El-Tahrir Street, Dokki, Cairo, Egypt
}

Received: 7 June 2005. Accepted: 10 March 2006

\begin{abstract}
Soil as a part of the environment receives pollutants from all types of human activities. Heavy metals originating from various organic waste sources and industrial activities accumulate in the soil surface, and their fate depends not only on the types and amounts of waste applied, but on soil properties. Furthermore, soils differ in their retention power for various heavy or trace elements. Twelve soil samples were selected from different sites irrigated with industrial and sewage wastes at Helwan city (Cairo Governorate) in the north and El-Saff (Giza Governorate) in the south. Separation of clay, silt and sand fractions were carried out. Chemical analyses of trace elements in the form of total and available contents ( $\mathrm{Fe}, \mathrm{Mn}, \mathrm{Zn}$ and $\mathrm{Pb}$ ) were determined in each fraction. The obtained results show that the average amounts of heavy metals in different fractions are related to the particle size of the soil especially the fine fraction. Heavy metals content was always in the surface layers higher than sub-surface. All metals were highest in clay fraction followed by silt and sand fractions respectively. This investigation discussed the importance of the fine fractions in the accumulation of heavy metals by coordination number in the lattice structure.
\end{abstract}

Key-words: Heavy metals, pollution.

\section{Introduction}

Soil as a part of the environment receives pollutant from all types of human activities. On the other hand plants grown may absorb toxic materials that cause problems at some points in the food chain. Therefore soils are considered as sinks for trace elements; hence, they play an important role in environmental cycling of these elements. Abdel-Sabour and Mohamed (1995) found that waste water irrigation and the application of organic residues waste to agricultural land have added to the heavy metals pool in soils. In Egypt, Abdel Aziz (1992) reported that the average content of total $\mathrm{Fe}, \mathrm{Mn}, \mathrm{Zn}$, $\mathrm{Cu}, \mathrm{Pb}$ and $\mathrm{Cd}$ in the surface layers of El-Saff soils polluted by industrial wastes of iron and steel outlet were $15.56 \%, 2340,399,166.5,129$ and $1.95 \mathrm{ppm}$ respectively. Badawy and Helal (1997) found that the content of heavy metals $\mathrm{Fe}, \mathrm{Mn}, \mathrm{Cu}, \mathrm{Zn}, \mathrm{Cd}, \mathrm{Co}, \mathrm{Ni}, \mathrm{Pb}$ and $\mathrm{Cr}$ were increasing to be as high as $280-590 \%$ of the initial contents after irrigation with industrial waste water up to four years in Helwan soils.
Abdel Aal et al. (1991) studied the accumulation of heavy metals i.e. $\mathrm{Fe}, \mathrm{Mn}, \mathrm{Zn}, \mathrm{Cu}, \mathrm{Pb}, \mathrm{Ni}$ and $\mathrm{Cd}$ in Abu-Rawash farm sandy soils irrigated with sewage effluents for different durations up to 10 years. Results showed a marked accumulation of the tested elements through both surface and subsurface soil layer particularly the most upper layer $(5 \mathrm{~cm})$. In the same farm, El Gendi et al. (1997) found that the total contents of $\mathrm{Zn}, \mathrm{Cu}, \mathrm{Mn}$ and $\mathrm{Fe}$ after 14 years of wastewater irrigation were approximately $170,125,53$ and 5 times greater than unpolluted soil. Abdel-Hady (1992) added that the extractable amount of $\mathrm{Mn}$ in the soils of Shoubra El-Kheima fluctuated from 39 to $79 \mathrm{ppm}$, while that of extractable $\mathrm{Fe}$ varied between 314 to $516 \mathrm{ppm}$. The highest amounts of extractable Mn were obtained from soils near the Delta Steel Factory.

The aim of this work is to determine the distribution of some heavy metals in different particle size fractions of soils irrigated with polluted water sources. 


\section{Materials and methods}

Twelve soil samples (6 profiles) were chosen from different locations at Helwan and El-Saff (Figure 1). Such area is exposed to a serious chemical pollution derived from several industries established there, i.e. Iron and Steel, weaving and spinning, coal, and others. Such pollution is carried by air and waste water. Soil samples were collected at two depths $(0-20 \mathrm{~cm}$ and $20-40 \mathrm{~cm}$ ). The samples were air-dried, crushed to pass a $2 \mathrm{~mm}$ sieve, then subjected to different physical and chemical analyses according to Page et al. (1982). Soil samples were prepared for heavy metals analyses in different fractions. Separation of clay, silt and sand were carried out according to the method described by Shuman (1985). Distribution of heavy metals in each soil fraction ( $\mathrm{Fe}, \mathrm{Mn}, \mathrm{Zn}$, and $\mathrm{Pb}$ ) content were determined according to the methods of Jackson (1969). Available content of heavy metals was estimated according to the method of Lindsay and Norvell (1978) using DTPA solution. Determinations of heavy metals were carried out using atomic absorption spectrophotometer.

\section{Results and discussion}

The general properties of the investigated area (Table 1) show that all profiles are sandy, sandy loam, loamy sand, clay loam and silty loam. Organic matter content is generally low. Calcium

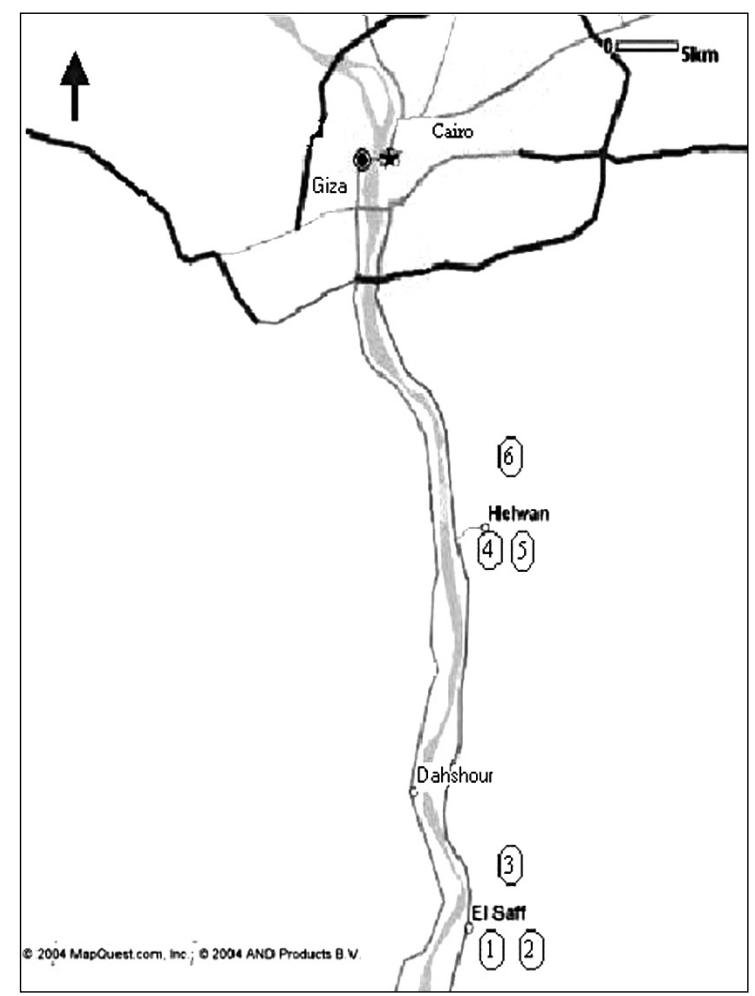

Figure 1. Location of the sampled profiles.

carbonate content is higher in El-Saff soils compared to Helwan soils. Soils under irrigation with polluted sources are non saline as indicated by their EC values which range from 1.97 to $3.75 \mathrm{dS} / \mathrm{m}$. Soil reaction lies within the neutral to slightly alkaline range, as indicated by $\mathrm{pH}$ values which range between 7.3 to 7.9 .

Table 1. Some physical and chemical characteristics of the studied soil samples.

\begin{tabular}{|c|c|c|c|c|c|c|c|c|c|c|c|}
\hline \multirow[t]{2}{*}{ Location } & \multirow{2}{*}{$\begin{array}{c}\text { Sample } \\
\text { No }\end{array}$} & \multirow{2}{*}{$\begin{array}{c}\text { Profile } \\
\text { No }\end{array}$} & \multirow{2}{*}{$\begin{array}{l}\text { Depth } \\
\mathrm{cm}\end{array}$} & \multirow{2}{*}{$\begin{array}{c}\mathrm{PH} \\
1: 2.5\end{array}$} & \multirow{2}{*}{$\begin{array}{c}\mathrm{EC} \\
\mathrm{dS} / \mathrm{m}\end{array}$} & \multirow{2}{*}{$\begin{array}{c}\mathrm{CaCO}_{3} \\
\%\end{array}$} & \multirow{2}{*}{$\begin{array}{c}\mathrm{OM} \\
\%\end{array}$} & \multicolumn{3}{|c|}{ Particle size distribution } & \multirow[t]{2}{*}{ Texture } \\
\hline & & & & & & & & $\begin{array}{c}\text { Clay } \\
\%\end{array}$ & $\begin{array}{c}\text { Silt } \\
\%\end{array}$ & $\begin{array}{c}\text { Sand } \\
\%\end{array}$ & \\
\hline \multirow[t]{6}{*}{ El-Saff } & 1 & 1 & $0-20$ & 7.5 & 3.21 & 10.51 & 2.01 & 17.45 & 6.75 & 75.80 & Sandy loam \\
\hline & 2 & & $20-40$ & 7.6 & 2.51 & 13.24 & 0.74 & 8.55 & 7.47 & 83.98 & Loamy sand \\
\hline & 3 & 2 & $0-20$ & 7.4 & 2.88 & 9.45 & 1.95 & 12.73 & 8.34 & 78.93 & Sandy loam \\
\hline & 4 & & $20-40$ & 7.8 & 1.97 & 10.47 & 0.64 & 8.23 & 5.25 & 86.52 & Sand \\
\hline & 5 & 3 & $0-20$ & 7.7 & 2.54 & 10.74 & 1.88 & 17.43 & 5.78 & 76.79 & Sandy loam \\
\hline & 6 & & $20-40$ & 7.8 & 2.21 & 12.43 & 0.75 & 7.36 & 8.32 & 84.32 & Loamy sand \\
\hline \multirow[t]{6}{*}{ Helwan } & 7 & 4 & $0-20$ & 7.6 & 3.21 & 4.21 & 1.75 & 37.45 & 29.52 & 33.03 & Clay loam \\
\hline & 8 & & $20-40$ & 7.5 & 2.25 & 5.32 & 1.11 & 27.95 & 33.41 & 38.64 & Clay loam \\
\hline & 9 & 5 & $0-20$ & 7.8 & 3.27 & 5.31 & 1.94 & 18.55 & 39.77 & 41.68 & Loam \\
\hline & 10 & & $20-40$ & 7.9 & 2.92 & 6.12 & 1.73 & 12.34 & 17.66 & 70.00 & Silty loam \\
\hline & 11 & 6 & $0-20$ & 7.5 & 3.75 & 3.45 & 1.85 & 30.55 & 40.77 & 28.68 & Clay loam \\
\hline & 12 & & $20-40$ & 7.3 & 2.78 & 4.22 & 1.14 & 26.91 & 34.21 & 38.88 & Loam \\
\hline
\end{tabular}


Table 2. Distribution of total and available content of heavy metals among various particle size fraction.

\begin{tabular}{|c|c|c|c|c|c|c|c|c|c|c|}
\hline \multirow{2}{*}{$\begin{array}{l}\text { Sample } \\
\text { No }\end{array}$} & \multirow{2}{*}{$\begin{array}{l}\text { Depth } \\
\mathrm{Cm}\end{array}$} & \multirow[t]{2}{*}{ Fraction } & \multicolumn{4}{|c|}{ Total content $(\mathrm{ppm})$} & \multicolumn{4}{|c|}{ DTPA extractable (ppm) } \\
\hline & & & $\begin{array}{c}\mathrm{Fe} \\
\mathrm{g} / 100 \mathrm{~g}\end{array}$ & $\mathrm{Mn}$ & $\mathrm{Zn}$ & $\mathrm{Pb}$ & $\mathrm{Fe}$ & $\mathrm{Mn}$ & $\mathrm{Zn}$ & $\mathrm{Pb}$ \\
\hline \multirow[t]{4}{*}{1} & $0-20$ & Clay & 11.44 & 1534 & 623 & 475 & 10.4 & 6.3 & 6.1 & 5.3 \\
\hline & & Silt & 8.49 & 854 & 453 & 445 & 7.2 & 5.6 & 5.4 & 4.8 \\
\hline & & Sand & 0.71 & 70 & 62 & 47 & 1.1 & 0.9 & 0.9 & 0.8 \\
\hline & Average & & 6.88 & 819 & 379 & 322 & 6.2 & 4.3 & 4.1 & 3.6 \\
\hline \multirow[t]{4}{*}{2} & $20-40$ & Clay & 4.23 & 1232 & 561 & 387 & 5.5 & 4.5 & 4.1 & 3.9 \\
\hline & & Silt & 3.24 & 635 & 322 & 352 & 4.2 & 3.9 & 3.2 & 2.9 \\
\hline & & Sand & 0.53 & 60 & 50 & 40 & 0.9 & 0.7 & 0.6 & 0.5 \\
\hline & Average & & 2.67 & 642 & 311 & 260 & 3.5 & 3.0 & 2.6 & 2.4 \\
\hline \multirow[t]{4}{*}{3} & $0-20$ & Clay & 15.45 & 1345 & 677 & 467 & 23.8 & 10.7 & 5.9 & 4.8 \\
\hline & & Silt & 10.63 & 735 & 523 & 423 & 11.4 & 6.4 & 4.8 & 3.9 \\
\hline & & Sand & 1.23 & 71 & 66 & 46 & 2.1 & 1.3 & 1.1 & 0.9 \\
\hline & Average & & 9.10 & 717 & 422 & 312 & 12.4 & 6.1 & 3.9 & 3.2 \\
\hline \multirow[t]{4}{*}{4} & $20-40$ & Clay & 6.76 & 1156 & 432 & 392 & 6.6 & 4.4 & 4.1 & 3.9 \\
\hline & & Silt & 3.43 & 532 & 392 & 387 & 3.2 & 3.4 & 3.2 & 2.8 \\
\hline & & Sand & 0.92 & 66 & 61 & 41 & 1.1 & 0.9 & 0.8 & 0.7 \\
\hline & Average & & 3.70 & 585 & 295 & 273 & 3.6 & 2.9 & 2.7 & 2.5 \\
\hline \multirow[t]{4}{*}{5} & $0-20$ & Clay & 13.78 & 1415 & 583 & 468 & 15.6 & 6.5 & 5.9 & 5.1 \\
\hline & & Silt & 7.53 & 653 & 478 & 411 & 6.4 & 3.5 & 3.1 & 2.9 \\
\hline & & Sand & 0.85 & 62 & 58 & 45 & 0.9 & 0.8 & 0.7 & 0.6 \\
\hline & Average & & 7.39 & 710 & 373 & 308 & 7.6 & 3.6 & 3.2 & 2.9 \\
\hline \multirow[t]{4}{*}{6} & $20-40$ & Clay & 5.23 & 1029 & 392 & 387 & 6.2 & 3.7 & 3.2 & 3.1 \\
\hline & & Silt & 3.56 & 457 & 302 & 323 & 3.2 & 2.4 & 2.1 & 1.9 \\
\hline & & Sand & 0.33 & 57 & 52 & 40 & 0.7 & 0.5 & 0.4 & 0.3 \\
\hline & Average & & 3.04 & 514 & 249 & 250 & 3.4 & 2.2 & 1.9 & 1.8 \\
\hline \multirow[t]{4}{*}{7} & $0-20$ & Clay & 21.78 & 3245 & 847 & 523 & 92.1 & 45.2 & 7.3 & 6.2 \\
\hline & & Silt & 14.55 & 2932 & 653 & 487 & 72.6 & 31.3 & 6.2 & 5.4 \\
\hline & & Sand & 1.78 & 83 & 75 & 50 & 3.4 & 2.5 & 1.1 & 0.9 \\
\hline & Average & & 12.70 & 2086 & 525 & 353 & 56.0 & 26.3 & 4.9 & 4.2 \\
\hline \multirow[t]{4}{*}{8} & $20-40$ & Clay & 15.25 & 2415 & 692 & 434 & 65.3 & 30.7 & 5.4 & 4.3 \\
\hline & & Silt & 11.87 & 1875 & 437 & 420 & 52.4 & 20.4 & 4.2 & 3.2 \\
\hline & & Sand & 0.95 & 75 & 63 & 40 & 2.1 & 1.1 & 0.8 & 0.7 \\
\hline & Average & & 9.36 & 1455 & 397 & 298 & 39.9 & 17.4 & 3.5 & 2.7 \\
\hline \multirow[t]{4}{*}{9} & $0-20$ & Clay & 17.34 & 2973 & 689 & 485 & 51.2 & 25.7 & 5.2 & 5.1 \\
\hline & & Silt & 10.53 & 1954 & 541 & 450 & 44.2 & 21.4 & 3.9 & 3.4 \\
\hline & & Sand & 0.85 & 72 & 70 & 48 & 1.3 & 1.1 & 0.9 & 0.8 \\
\hline & Average & & 9.57 & 1666 & 433 & 327.6 & 32.2 & 16.1 & 3.3 & 3.1 \\
\hline \multirow[t]{4}{*}{10} & $20-40$ & Clay & 10.56 & 2321 & 544 & 402 & 38.9 & 18.8 & 4.3 & 4.1 \\
\hline & & Silt & 8.47 & 1654 & 421 & 411 & 32.5 & 13.4 & 3.2 & 3.1 \\
\hline & & Sand & 0.75 & 65 & 63 & 42 & 0.9 & 0.7 & 0.8 & 0.5 \\
\hline & Average & & 6.59 & 1347 & 343 & 285 & 24.1 & 11.0 & 2.8 & 2.6 \\
\hline \multirow[t]{4}{*}{11} & $0-20$ & Clay & 20.23 & 3745 & 748 & 492 & 85.4 & 30.5 & 5.9 & 4.4 \\
\hline & & Silt & 15.78 & 2953 & 532 & 420 & 71.3 & 25.3 & 4.7 & 3.7 \\
\hline & & Sand & 1.34 & 71 & 58 & 49 & 3.3 & 1.4 & 0.9 & 0.8 \\
\hline & Average & & 12.45 & 2256 & 446 & 320 & 53.3 & 19.1 & 3.8 & 3.0 \\
\hline \multirow[t]{4}{*}{12} & $20-40$ & Clay & 15.86 & 2943 & 547 & 432 & 65.4 & 22.4 & 4.8 & 3.9 \\
\hline & & Silt & 11.32 & 1953 & 427 & 401 & 55.1 & 17.3 & 3.2 & 2.8 \\
\hline & & Sand & 0.85 & 63 & 51 & 42 & 1.1 & 0.9 & 0.8 & 0.7 \\
\hline & Average & & 9.34 & 1653 & 342 & 292 & 40.5 & 13.5 & 2.9 & 2.5 \\
\hline
\end{tabular}


Total heavy metals in soils. Distribution of heavy metals between various particle size fractions in El-Saff and Helwan soils is listed in table 2 they have high amounts of heavy metals due to the large amounts of wastes of the industrial complex at Helwan area, soil problems arise in the region extended from Helwan southward to El-Saff. Industrial wastes which contain large amounts of heavy metals are dumped into the irrigation canals, and resulted with industrial wastes includes large changes in its chemical properties. Iron, manganese, zinc and lead are the main heavy metals pollutants coming from the industrial wastes. The data presented in table 2 indicate that in all soils samples, the highest contents of heavy metals were in the clay $<$ silt $<$ sand fraction respectively. With regard to the average values in each layer it is found that the average total iron content ranged between 2.67 and $12.70 \mathrm{~g} / 100 \mathrm{~g}$, manganese from 514 to $2256 \mathrm{ppm}$, zinc from 249 to $525 \mathrm{ppm}$ and lead from 250 to $353 \mathrm{ppm}$. For the samples no. (7) and (11) it is noticed that the highest content of total iron occurs in the surface layer (average 12.70 and $12.45 \mathrm{~g} / 100 \mathrm{~g}$ respectively) due to irrigation with liquid wastes from Iron and Steel factory and ElCoke factory. Liquid effluent of factories contains a high quantity of suspended matter rich in iron, that the effluent has reddish colour and which reflects on soil colour. Long term irrigation with such liquid waste led to the observable increase of total iron in the soil in spite of their light texture. These concentrations decreased with increasing the distance from the industrial area. In addition, sample (7) contains the highest values of $\mathrm{Pb}$ due to dust fall, smokes and over flow of liquid wastes loaded by suspended materials rich in these metals especially $\mathrm{Pb}$ onto the soils beside the factories.

El-Taieb (1981) confirmed that the dust fall at Helwan area is an important pollutant source which exceed 10 times its standard quantity they reached 25 tons $/ \mathrm{mile}^{2} /$ month (Stern et al., 1974). In all cases average values of heavy metals diminished downward the soil layers. Dominance of such heavy metals in the area followed the decreasing order: $\mathrm{Fe}<\mathrm{Mn}<\mathrm{Zn}<\mathrm{Pb}$. On the other hand, data in table 2 show the amounts of DTPA-extractable ( $\mathrm{Fe}, \mathrm{Mn}, \mathrm{Zn}$ and $\mathrm{Pb})$ in clay, silt and sand fractions in each surface (0$20 \mathrm{~cm})$ and subsurface $(20-40 \mathrm{~cm})$ layers. The average amounts ranged from 3 to $56 \mathrm{ppm}, 2$ to 26ppm, 2 to $5 \mathrm{ppm}$ and 2 to $4 \mathrm{ppm}$ for $\mathrm{Fe}, \mathrm{Mn}$, $\mathrm{Zn}$ and $\mathrm{Pb}$, respectively. In all cases, the highest values were found in the clay fraction while the lowest values were found in the sand fraction; due to the soils differ in their retention power of each size fraction for various heavy metals. Furthermore values of all extractable elements decreased with the depth, so the highest values were found in the surface layer. These results indicate that the heavy metals originating from various organic waste sources accumulate in the surface and their fate depends on the chemical and physical properties of the soil.

For DTPA-extractable iron and manganese, the highest values were in sample (7), which is considered the nearest location of Iron and Steel factory. For zinc and lead, it is clear that, the clay and silt fractions contain high amounts of zinc and led compared to the sand fraction. These results agree with Andersson (1979), who discussed the retention and mechanism adsorption of zinc and lead with fine fractions of soil and stated that zinc element has ionic radius $0.74 \mathrm{~A}^{0}$, which make both fit into6-coordinated octahedral positions in the layer silicate clay minerals. $\mathrm{Mn}$ and $\mathrm{Fe}$ also have coordination number of 6 and they can be captured in octahedral positions, in addition to the hydrated oxides. These oxides are often precipitated as islands on the surface of silicate minerals, with large specific surfaces. Moreover, these oxides can also be found precipitated as surface coating in channels and fractures. For lead it is present in both clay and silt fractions by almost the same concentration, and these concentrations were several times that of the sand fraction. Lead has coordination number higher than 6 and could not easily be enriched in the octahedral sites of the secondary silicate minerals. Andersson (1979) mentioned that the enrichment of $\mathrm{Pb}$ in the finer fraction may probably take place when it was released by the weathering processes as irrigation with polluted water or from fall outs. These elements, like most other heavy metals, are strongly adsorbed to functional groups on the particle surface and may then occluded, for example in hydrated oxides precipitating on the same surfaces. On the other hand it can be stated the data refer to the positive trend between total and extractable iron content. While this trend has exception in case of other elements. 


\section{Conclusions}

The data obtained from this current investigation draw the attention to the impact and hazardous effect of the industrial wastes on soil contamination. The heavy metals are more concentrated in the surface layers of soil horizons which is the most important media for growing the seedlings. The impact of heavy metals are more pronounced on the fine textured soils since these elements are absorbed on the lattice of clay minerals as well as the free aluminum silicate oxides. Soil contamination with heavy metal are greatly influenced by the source of industrial wastes, as in these cases of Steel and Coke factories at El-Saff and Helwan. Also another factor is whether the wastes are polluted in irrigation water or the fall out of the suspended matter i.e. windborne. Therefore industrial wastes have to be carefully treated to eliminate heavy metals before reaching the soil.

\section{References}

Abdel-Aal R.S., Abbas H.H., Rabie M.H., Khalil M.E. 1991. Accumulation of micronutrients and heavy metals in sandy soils irrigated with sewage water. Ann. Agric. Sci.; Moshtohor., 29:1811.

Abdel Aziz W.H. 1992. Study on soil pollution in El-Saff Region. M. Sc. Thesis, Fac. Agric., Ain Shams Univ., Egypt.

Abdel-Hady B.A. 1992. The effect of organic matter on the environmental pollution of Shoubra El-Kheima. M. Sc. Thesis, Institute of Environmental Sciences, Ain Shams Univ., Egypt.

Abdel-Sabour M.F., Mohamed A.M. 1995. Effect of biosolid compost rate of application on corn yield and heavy metal content. Egypt J. Agron., 20:47.

Andersson A. 1979. On the distribution of heavy metals as compared to some other elements between grain size fraction. Swedish J. Agric. Res., 9:7.

Badawy S.H., Helal M.I. 1997. Impacts of heavy metals of sewage effluent on soils and plants of Helwan area. J. Agric. Sci., Mansoura Univ., 22:4737.

El-Gendi S.A., Badaway S.H., Helal M.I. 1997. Mobility of some heavy metals nutrients in sandy soils irrigated with sewage effluent. J. Agric. Sci. Mansoura Univ., Egypt. 22:3535.

El-Taieb N.M. 1981. Some studies on air pollution in Helwan industrial area. M.Sc. Thesis, Faculty of Sci, Cairo Univ., Egypt.

Jackson M.L. 1969. Soil Chemical Analysis, Advanced course. Published by the author, Dept. of Soils, Univ. of Wisc., Madison, USA.

Lindsay W.L., Norvell W.A. 1978. Development of a DTPA soil test for zinc, iron, manganese and copper. Soil Sci. Soc. Am. J., 42:421.

Page A.L., Miller R.H., Kenny D.R. 1982. Methods of Soil Analysis. Part 2. $2^{\text {nd }}$ Edition Amer. Soc. Agron, Madison.

Shuman L.M. 1985. Fractional methods for soil microelements. Soil Sci., 140:11.

Stern A.C., Wohlers H.C., Baube R.W., Lawry W.P. 1974. Fundamental of Air Pollution. Academic Press, London. 